\title{
Antimicrobial activity of amurca (olive oil lees) extract against selected foodborne pathogens
}

\author{
Sana JANAKAT ${ }^{1 *}$, Anas Abdel Rauof AL-NABULSI ${ }^{1}$, Sabika ALLEHDAN ${ }^{1}$, \\ Amin Naser OLAIMAT², Richard Alan HOLLEY ${ }^{2}$
}

\begin{abstract}
The antimicrobial activity of a methanolic extract of amurca (olive oil lees) was determined against both Gram-positive (L. monocytogenes and S. aureus) and Gram-negative (E. coli O157:H7 and S. enteritidis) foodborne pathogens at $10^{\circ} \mathrm{C}$ or $37^{\circ} \mathrm{C}$ using microdilution and disk diffusion methods, and its relative activity was compared to selected antibiotics. Minimum inhibitory (MIC) and minimum bactericidal (MBC) concentrations of amurca extract ranged from 60 to $80 \mu \mathrm{l} / \mathrm{ml}$ at $37^{\circ} \mathrm{C}$ after $24 \mathrm{~h}$ against all tested strains. At $10^{\circ} \mathrm{C}$, amurca was more inhibitory with $\mathrm{MIC}$ and $\mathrm{MBC}$ values of $40 \mathrm{and} 60 \mu \mathrm{l} / \mathrm{ml}$, respectively, after $7 \mathrm{~d}$ against tested strains. Amurca at $40 \mu \mathrm{l} / \mathrm{ml}$ reduced numbers of tested pathogens by 2.5 to $3.2 \log _{10} \mathrm{CFU} / \mathrm{ml}$ at $10^{\circ} \mathrm{C}$ after $7 \mathrm{~d}$, but was not inhibitory at $37^{\circ} \mathrm{C}$ after $24 \mathrm{~h}$. Protein prepared from amurca was not antimicrobial. The relative antimicrobial activity (inhibition zone ratio) of $80 \mu \mathrm{l} / \mathrm{ml}$ amurca methanolic extract compared to chloramphenicol, erythromycin, gentamycin and tetracycline ranged from 0.36 to 1.0 against Gram-negative and from 0.45 to 2.0 against Gram-positive bacteria. In addition, amurca extract inhibited E. coli O157:H7 02-0628 and S. aureus 26127 which were resistant to tetracycline and chloramphenicol, respectively.
\end{abstract}

Keywords: amurca; foodborne pathogens; antimicrobial activity; olive oil; phenolic compounds.

Practical Application: Amurca extract showed potent antimicrobial activity against foodborne pathogens.

\section{Introduction}

Olive trees (Olea europeaea L) belong to the Oleaceae family which is comprised of 30 species, including jasmine (Jasminum), lilac (Syringa), and ash (Fraxinus) (Niaounakis \& Halvadakis, 2006). Olive trees are ancient plants and fossils from the Tertiary period ( 1 million years ago) have been found in the Mediterranean basin. Moreover, artefacts such as stone mortars and mills used for olive processing go back to the year $5000 \mathrm{BC}$ (Harwood \& Aparicio, 2000). There are more than 850 million olive bearing trees worldwide, of which about 10 million occur in Jordan (Niaounakis \& Halvadakis, 2006; Hashemite Kingdom of Jordan, 2007). The main products of cultivated olive trees are table olives and olive oil (Amici et al., 1991).

Olive oil can be produced either by traditional discontinuous pressing, or by a continuous centrifugation cycle (Kapellakis et al., 2008). Olive oil is the major product of the olive fruit milling process and generates, in addition to the solid waste or de-oiled cake, semi-solid and aqueous liquor by-products, including olive oil mill waste water and olive oil lees (Amurca) (Caputo et al., 2003; Niaounakis \& Halvadakis, 2006).

Amurca is a dark, bitter-tasting, sticky, viscous liquid, which settles at the bottom of olive oil containers over time (Niaounakis \& Halvadakis, 2006). It is abundant in Jordanian olive oil extracted under low pressure in traditional mills. Historically, amurca has been used by Mediterranean farmers as a herbicide, pesticide, fungicide and fertilizer. It has also been used as a dried fruit preservative according to ancient records from the area, and has found use as a polish for floors and has been used for oiling leather, wood, metals, and axles (Niaounakis \& Halvadakis, 2006; Quiles et al., 2006; Smith \& Secoy, 1975).

Amurca is composed of fat (49.4\%), water (47.3\%), carbohydrate $(0.7 \%)$, protein $(0.7 \%)$, ash $(0.9 \%)$, and has a relatively high content of phenolic compounds ( $289 \mathrm{mg}$ gallic acid equivalent $/ 100 \mathrm{~g}$ ) including oleuropein, isopropyl-5-methyl phenol, sinapic acid, luteolin, gallic acid, kaempferol and 3-hydroxy phenol (Janakat \& Hammad, 2013). These phenolic compounds showed strong inhibitory effects against several spoilage and pathogenic bacteria; for example, oleuropein inhibited production of enterotoxin B by Staphylococcus aureus (Tranter et al., 1993), inhibited growth of Salmonella Enteritidis (Tassou \& Nychas, 1995), and germination of B. cereus $\mathrm{T}$ spores (Tassou et al., 1991).

The high concentration of phenolic compounds in olive oil contributes significantly toward its antioxidant and antimicrobial activity (Capasso et al., 1995; Kecel \& Robinson, 2002; Markin et al., 2003; Pereira et al., 2006). The antimicrobial activity of oleuropein, hydroxytyrosol and tyrosol in virgin olive oil stems from their ability to interact with phosphatidylglycerol at the surface of the bacterial cell wall (Casas-Sanchez et al., 2007; Medina et al., 2006; Soler-Rivas et al., 2000). 
Several studies have found that virgin olive oil, olive fruit, olive oil mill waste water, and olive leaves possessed antimicrobial activity against a broad spectrum of microorganisms including Gram-negative and Gram-positive bacteria, fungi, viruses, and parasitic protozoan (Medina et al., 2006; Pereira et al., 2007; Ramos-Cormenzana et al., 1996; Soler-Rivas et al., 2000; Sudjana et al., 2009). However, no studies have examined the antimicrobial activity of amurca. Therefore, the objective of the current work was to evaluate aspects of the antimicrobial activity of amurca against a group of foodborne pathogens.

\section{Materials and methods}

\subsection{Amurca samples}

Amurca was obtained from a local olive oil mill in the province of Ajloun, Jordan. The samples were centrifuged at $3000 \mathrm{rpm}(723 \mathrm{xg})$ for $20 \mathrm{~min}$ to sediment the amurca and allow its better separation from the remaining olive oil. The samples were kept at $-18^{\circ} \mathrm{C}$ until use.

\subsection{Foodborne pathogens}

Escherichia coli O157:H7 strains 02-0304 and 02-0628 which had become non-pathogenic (verotoxigenic negative) during storage were provided by Rafiq Ahmed, National Microbiology Laboratory, Public Health Agency, Canadian Science Centre for Human and Animal Health, Winnipeg, MB, Canada. Listeria monocytogenes strains 1 and 4 were isolated from processed meat and dairy products, respectively, in Jordan. Salmonella Enteritidis was provided by the Jordan Food and Drug administration, and Staphylococcus aureus strains 25923 and 26127 were from the Department of Nutrition and Food Technology, Jordan University of Science and Technology.

\subsection{Amurca methanolic extract}

Two hundred grams of amurca were soaked in $99 \%$ methanol at a ratio $1: 3(\mathrm{w} / \mathrm{v})$ for $24 \mathrm{~h}$ at $4{ }^{\circ} \mathrm{C}$. The mixture was homogenized using a household blender for one min at full speed, filtered through a double layer of cheese cloth, and centrifuged at $3000 \mathrm{rpm}$ (723 xg) for $15 \mathrm{~min}$. The supernatant was dried using a rotary evaporator (model 4001, Heidolph Laborota, Schwabach, Germany) at $40{ }^{\circ} \mathrm{C}$ and $120 \mathrm{rpm}$. The dried matter was re-suspended in a ratio of 1:2 with $2 \%(\mathrm{w} / \mathrm{v})$ dimethyl sulfoxide (DMSO) (Sigma-Aldrich, St Louis, MO, USA) and was sterilized by filtration with a disposable syringe filter unit $(0.20 \mu \mathrm{m})$ (Toyo Roshi Kaisha, Ltd., Tokyo, Japan) and kept at $-18{ }^{\circ} \mathrm{C}$ until used for antimicrobial assays.

\subsection{Protein precipitation by ammonium sulphate}

Protein in $100 \mathrm{ml}$ of the amurca methanolic extract was precipitated by slowly adding ammonium sulphate until its concentration reached $100 \%$. The mixture was centrifuged at $3000 \mathrm{rpm}(723 \mathrm{xg})$ for $20 \mathrm{~min}$ at $4{ }^{\circ} \mathrm{C}$. The supernatant was dialyzed against $0.05 \mathrm{M}$ phosphate buffer, $\mathrm{pH} 7.2$ for $24 \mathrm{~h}$ at $4{ }^{\circ} \mathrm{C}$ and the precipitate was re-suspended to its original volume using the same buffer. The dialyzed portion was sterilized by filtration with a disposable syringe filter unit $(0.20 \mu \mathrm{m})$ and kept for antimicrobial assay (Janakat et al., 2004).

\subsection{Determination of Amurca protein by the lowry method}

A dilution series of a protein standard $(0.3 \mu \mathrm{l} / \mathrm{mL}$ bovine serum albumin in distilled water) was prepared to yield concentrations of 0.03 to $0.18 \mu \mathrm{l} / \mathrm{ml}$. Twenty microliters amurca samples were taken and protein concentration was determined using the Lowry method (Lowry et al., 1951).

\subsection{Antimicrobial assay}

(a) Preparation of culture. Test cultures (E. coli O157:H7 strains 02-0304 and 02-0628, L. monocytogenes strains 1 and 4, S. Enteritidis, and S. aureus strains 25923 and 26127) were kept at $-40^{\circ} \mathrm{C}$ in Brain Heart Infusion (BHI, Oxoid Ltd, Basingstoke, UK) broth containing $20 \%$ glycerol. Working cultures were prepared by transferring a single colony to Tryptone Soy Broth, TSB (Oxoid Ltd.) and incubated $37^{\circ} \mathrm{C}$ for $24 \mathrm{~h}$. Then $100 \mu \mathrm{l}$ was transferred to $10 \mathrm{ml} \mathrm{TSB}$ prior to the experiment and incubated for $24 \mathrm{~h}$ at $37^{\circ} \mathrm{C}$.

(b) Microbroth dilution. Minimum Inhibitory (MIC) and Minimum Bactericidal (MBC) concentrations of amurca against tested organisms were determined as described by Al-Nabulsi et al. (2011) in Mueller Hinton (MH) broth (Himedia Ltd., Mambai, India). Ninety six well microtiter plates (Greiner Bio-One, CellStar ${ }^{\text {TM }}$, Italy) were used to evaluate the effects of different concentrations of methanolic amurca extract on the viability of foodborne pathogens in the present study. Of the $300 \mu \mathrm{l}$ well capacity, $250 \mu \mathrm{l}$ was used as follows: $100 \mu \mathrm{l}$ was from the tested culture diluted in $\mathrm{MH}$ broth to give a final inoculum of $6.0 \log _{10} \mathrm{CFU} / \mathrm{ml} ; 100 \mu \mathrm{l}$ of $\mathrm{MHB}$ was added, then 5,10 , 15 , or $20 \mu \mathrm{l}$ of sterile methanolic amurca mixture (containing $33.3 \%(\mathrm{w} / \mathrm{v})$ dry amurca extract) was added, and the volume was completed by the addition of $30,35,40$ or $45 \mu \mathrm{l}$ of sterile distilled water to give a final concentration $20,40,60$, or $80 \mu \mathrm{l} / \mathrm{ml}$ of methanolic amurca extract, respectively. Negative control wells contained $200 \mu \mathrm{MH}$ broth plus 20,15 or $10 \mu \mathrm{l}$ of sterile amurca methanolic extract, and the volume was completed by the addition of 30,35 or $40 \mu \mathrm{l}$ of sterile distilled water. Positive control wells contained $100 \mu \mathrm{l}$ culture mixed with $100 \mu \mathrm{l}$ of $\mathrm{MH}$ broth and $50 \mu \mathrm{l}$ of sterile distilled water. The purpose of the negative control was to enable the subtraction of its absorbance from the absorbance of other wells, since amurca had a dark color. Samples were incubated at $37^{\circ} \mathrm{C}$ for $24 \mathrm{~h}$ or at $10^{\circ} \mathrm{C}$ for $7 \mathrm{~d}$ and absorbance was read with a microplate reader at $620 \mathrm{~nm}$ (MR 5000, Dynatech, Mount Holly, NJ, USA). The MBC (the lowest concentration of antimicrobial required to kill $99.9 \%$ of the initial viable cells) was determined by plating $100 \mu \mathrm{l}$ of the samples in each well on Tryptone Soy Agar, TSA (Oxoid).

(c) Agar well diffusion. Methods by Janakat et al. (2005) and Gupat et al. (2008) were used with some modification. Samples of $100 \mu$ to yield a final concentration of $6 \log _{10} \mathrm{CFU} / \mathrm{ml}$ of each test organism were spread on the surface of $\mathrm{MH}$ agar, MHA (Himedia Ltd.) and allowed to stand for $30 \mathrm{~min}$ at room temperature. Then sterile blank disks containing $25 \mu \mathrm{l}$ sterile methanolic amurca extract $(80 \mu \mathrm{l} / \mathrm{ml})$ or sterile antibiotic disks 
containing chloramphenicol $(30 \mu \mathrm{g})$, erythromycin $(15 \mu \mathrm{g})$, gentamycin $(10 \mu \mathrm{g})$, or tetracycline $(30 \mu \mathrm{g})$ were placed on the surface of MHA and incubated at $37^{\circ} \mathrm{C}$ for $24 \mathrm{~h}$. The inhibition zones produced were recorded to the nearest $\mathrm{mm}$.

\subsection{Statistical analysis}

The data were analyzed using Statistical Analysis Software (SAS, version 7, 2000, USA). Factorial analysis of variance (ANOVA) was performed on all parameters. Means were calculated for all variables in the study and the least square means were used to determine significant differences. Findings with a $p$-value of $<0.05$ were considered to be statically significant.

\section{Results}

\subsection{Antimicrobial activity of amurca methanolic extract by microdilution at $10^{\circ} \mathrm{C}$ or $37^{\circ} \mathrm{C}$}

An obvious difference $(p<0.05)$ in the antimicrobial activity of different concentrations of amurca extract at 10 and $37^{\circ} \mathrm{C}$ was observed against the foodborne pathogens (Tables 1 , 2,3). Amurca extract was more inhibitory at $10{ }^{\circ} \mathrm{C}$ where the MIC and MBC were 40 and $60 \mu \mathrm{l} / \mathrm{ml}$, respectively, against all pathogens compared to 60 and $80 \mu \mathrm{l} / \mathrm{ml}$ except $L$. monocytogenes 4 and S. aureus 26127 which had MBC values of $60 \mu \mathrm{l} / \mathrm{ml}$ at $37^{\circ} \mathrm{C}$ (Table 1). Amurca concentration at 40 and $60 \mu \mathrm{l} / \mathrm{ml}$ reduced numbers of tested pathogens by $<0.5 \log _{10} \mathrm{CFU} / \mathrm{ml}$ and 2.5-9.8 $\log _{10} \mathrm{CFU} / \mathrm{ml}$, respectively, compared to control at $37{ }^{\circ} \mathrm{C}$ after $24 \mathrm{~h}$ (Table 2); while at $10^{\circ} \mathrm{C}$, pathogen numbers were reduced by 2.5-3.2 $\log _{10} \mathrm{CFU} / \mathrm{ml}$ and 9.0-9.5 $\log _{10} \mathrm{CFU} / \mathrm{ml}$ at 40 and $60 \mu \mathrm{l} / \mathrm{ml}$ amurca extract, respectively. Moreover, all organisms tested were not detected at 60 and $80 \mu \mathrm{l} / \mathrm{ml}$ amurca extract at 10 and $37^{\circ} \mathrm{C}$, respectively (Table 3).

\subsection{Antimicrobial activity of amurca methanolic extract by disk diffusion and its activity relative to selective antibiotics}

The antimicrobial activity of amurca extracts determined by the dilution method were confirmed by disk diffusion. The amurca methanolic extract at $80 \mu \mathrm{l} / \mathrm{ml}$ gave inhibitory zones of $9 \mathrm{~mm}$ with all Gram-negative and Gram-positive bacteria except for E. coli O157:H7 02-0628 and S. aureus 26127, which showed inhibitory zones of $10 \mathrm{~mm}$ and $20 \mathrm{~mm}$, respectively (Tables 4, 5).

Table 1. MIC and MBC $(\mu \mathrm{l} / \mathrm{ml})$ of selected foodborne pathogens strains at $37^{\circ} \mathrm{C}$ after $24 \mathrm{~h}$ or at $10^{\circ} \mathrm{C}$ after $7 \mathrm{~d}$.

\begin{tabular}{lcccc}
\hline \multirow{2}{*}{ Organism } & \multicolumn{2}{c}{$10^{\circ} \mathrm{C}$} & \multicolumn{2}{c}{$37^{\circ} \mathrm{C}$} \\
\cline { 2 - 5 } & $\mathrm{MIC}^{\mathrm{a}}$ & $\mathrm{MBC}^{\mathrm{b}}$ & $\mathrm{MIC}^{\mathrm{a}}$ & $\mathrm{MBC}^{\mathrm{b}}$ \\
\hline E. coli O157:H7 02-0628 & 40 & 60 & 60 & 80 \\
E. coli O157:H7 02-0304 & 40 & 60 & 60 & 80 \\
L. monocytogenes 1 & 40 & 60 & 60 & 80 \\
L. monocytogenes 4 & 40 & 60 & 60 & 60 \\
S. Enteritidis & 40 & 60 & 60 & 80 \\
S. aureus 26127 & 40 & 60 & 60 & 60 \\
S. aureus 25923 & 40 & 60 & 60 & 80 \\
\hline
\end{tabular}

a The lowest concentration at which no visible growth occurred. ${ }^{\mathrm{b}}$ The lowest concentration cause $99.9 \%$ reduction of initial inoculation.
The relative antimicrobial activity of $80 \mu \mathrm{l} / \mathrm{ml}$ amurca methanolic extract to chloramphenicol, erythromycin, gentamycin and tetracycline (calculated as a ratio of inhibition zones, amurca/antibiotic) ranged from 0.36 to 1.0 against Gram-negative bacteria (Table 4) and 0.45 to 2.0 against Grampositive bacteria (Table 5). It is notable that E. coli O157:H7 02-0628 and S. aureus 26127 were resistant to tetracycline and chloramphenicol, respectively, but the amurca extract at $80 \mu \mathrm{l} / \mathrm{ml}$ produced inhibitory zones of 10 and $20 \mathrm{~mm}$, respectively (Tables 4,5 ). The relative inhibitory activity of amurca in these instances was estimated to be 10- and 20-fold greater than the compared antibiotic.

\subsection{Effect of protein precipitated from Amurca extract on growth of foodborne pathogens}

When examined for inhibitory effects on pathogen growth, the proteins recovered after precipitation by ammonium sulfate from 40,60 or $80 \mu \mathrm{l} / \mathrm{ml}$ amurca extract did not prove inhibitory against tested strains. In these tests, bacterial numbers increased about $4 \log _{10} \mathrm{CFU} / \mathrm{ml}$ and reached 9.2 to $9.6 \log _{10} \mathrm{CFU} / \mathrm{ml}$ by $24 \mathrm{~h}$ at $37^{\circ} \mathrm{C}$ (Table 6).

\section{Discussion}

The amurca extract showed substantial antimicrobial activity against tested foodborne pathogens in the current study. The MIC values reported here were similar to those reported by Pereira et al. (2007) who found that extracted olive leaves inhibited the growth of E. coli and S. aureus with MIC values of $50 \mu \mathrm{l} / \mathrm{ml}$ and $25 \mu \mathrm{l} / \mathrm{ml}$, respectively, at $37^{\circ} \mathrm{C}$. In another study, Pereira et al. (2006) reported that the MICs of a Portuguese table olive extract against E. coli, Bacillus cereus, Bacillus subtilis, Staphylococcus aureus, Pseudomonas aeruginosa, and Klebsiella pneumonia, ranged from 10 to $100 \mu \mathrm{l} / \mathrm{ml}$ at $37^{\circ} \mathrm{C}$. B. cereus numbers were reduced by $2.7 \log _{10} \mathrm{CFU} / \mathrm{ml}$ in the presence of $5 \mu \mathrm{l} / \mathrm{ml}$ olive powder in BHI broth at $20^{\circ} \mathrm{C}$ (Ferrer et al., 2009).

Since proteins recovered after precipitation from the amurca extract did not inhibit the growth of tested foodborne pathogens, it is possible that the potent antimicrobial activity of amurca reported in the present study may have been caused by the phenolic compounds present (Table 6). This would be consistent with previous reports showing that phenolic compounds in olive products (olive fruit, olive oil, olive leaves) and olive oil by-products (olive oil mill waste water, olive cake) exhibited antibacterial activity (Capasso et al., 1995; Kecel \& Robinson, 2002; Markin et al., 2003; Pereira et al., 2006).

The antibacterial activity of phenolic compounds was believed due to their ability to inflict bacterial membrane damage and disrupt the cell wall peptidoglycan, which cause loss of structural integrity and leakage of intracellular cytoplasmic constituents such as protein, glutamate, potassium and phosphate (Caturla et al., 2005). Moreover, the hydroxyl group in phenolic compounds may bind the active sites of enzymes and change their substrate affinity. In addition, their lipid solubility and the degree of steric hindrance they cause may also contribute to their overall antimicrobial activity (Ceylan \& Fung, 2004). 
Table 2. Antimicrobial activity of amurca methanolic extract ( 40 to $80 \mu \mathrm{l} / \mathrm{ml}$ ) against selected foodborne pathogens strains at $37^{\circ} \mathrm{C}$ after $24 \mathrm{~h}$.

\begin{tabular}{|c|c|c|c|c|c|}
\hline Organism & $\begin{array}{l}\text { Initial number } \\
\left(\log _{10} \mathrm{CFU} / \mathrm{ml}\right)\end{array}$ & $\begin{array}{c}\text { Control number, } 24 \mathrm{~h} \\
\left(\log _{10} \mathrm{CFU} / \mathrm{ml}\right)\end{array}$ & $\begin{array}{c}\text { Amurca concentration } \\
(\mu \mathrm{l} / \mathrm{ml})\end{array}$ & $\begin{array}{c}\text { Count after treatment, } \\
24 \mathrm{~h}\left(\log _{10} \mathrm{CFU} / \mathrm{ml}\right)\end{array}$ & $\begin{array}{c}\text { Reduction* } \\
\left(\log _{10} \mathrm{CFU} / \mathrm{ml}\right)\end{array}$ \\
\hline E. coli $\mathrm{O} 157: \mathrm{H} 7$ 02-0628 & $6.0 \pm 0.05$ & $9.5 \pm 0.20$ & $\begin{array}{l}40 \\
60 \\
80\end{array}$ & $\begin{array}{c}9.5 \pm 0.10 \\
6.1 \pm 0.10 \\
\mathrm{ND}\end{array}$ & $\begin{array}{r}0.0 \\
-3.4 \\
-9.5\end{array}$ \\
\hline E. coli $\mathrm{O} 157: \mathrm{H} 7$ 02-0304 & $5.8 \pm 0.17$ & $9.3 \pm 0.20$ & $\begin{array}{l}40 \\
60 \\
80\end{array}$ & $\begin{array}{l}9.4 \pm 0.30 \\
6.8 \pm 0.06 \\
\mathrm{ND}\end{array}$ & $\begin{array}{l}+0.1 \\
-2.5 \\
-9.3\end{array}$ \\
\hline L. monocytogenes 1 & $5.3 \pm 0.05$ & $9.8 \pm 0.20$ & $\begin{array}{l}40 \\
60 \\
80\end{array}$ & $\begin{array}{l}9.7 \pm 0.10 \\
5.8 \pm 0.10 \\
\mathrm{ND}\end{array}$ & $\begin{array}{l}-0.1 \\
-4.0 \\
-9.8\end{array}$ \\
\hline L. monocytogenes 4 & $5.7 \pm 0.17$ & $9.0 \pm 0.20$ & $\begin{array}{l}40 \\
60 \\
80\end{array}$ & $\begin{array}{l}9.2 \pm 0.30 \\
\text { ND } \\
\text { ND }\end{array}$ & $\begin{array}{l}+0.2 \\
-9.0 \\
-9.0\end{array}$ \\
\hline S. Enteritidis & $5.9 \pm 0.05$ & $9.3 \pm 0.20$ & $\begin{array}{l}40 \\
60 \\
80\end{array}$ & $\begin{array}{l}9.0 \pm 0.20 \\
6.3 \pm 0.30 \\
\mathrm{ND}\end{array}$ & $\begin{array}{l}-0.3 \\
-3.0 \\
-9.3\end{array}$ \\
\hline S. aureus 26127 & $5.6 \pm 0.16$ & $9.8 \pm 0.20$ & $\begin{array}{l}40 \\
60 \\
80\end{array}$ & $\begin{array}{l}9.3 \pm 0.20 \\
\text { ND } \\
\text { ND }\end{array}$ & $\begin{array}{l}-0.5 \\
-9.8 \\
-9.8\end{array}$ \\
\hline S. aureus 25923 & $5.6 \pm 0.26$ & $9.6 \pm 0.20$ & $\begin{array}{l}40 \\
60 \\
80\end{array}$ & $\begin{array}{c}9.3 \pm 0.20 \\
6.7 \pm 0.30 \\
\mathrm{ND}\end{array}$ & $\begin{array}{l}-0.3 \\
-2.9 \\
-9.6\end{array}$ \\
\hline
\end{tabular}

Values are expressed as mean $\pm \mathrm{SD}(\mathrm{n}=3)$. ND: Bacterial cells were not detected by transferring $0.1 \mathrm{ml}$ to $10 \mathrm{ml}$ TSB and no growth was observed after $24 \mathrm{~h}$ at $37^{\circ} \mathrm{C}$ (detection level was $\leq 1 \mathrm{CFU} / \mathrm{ml}$ ). ${ }^{\star}$ Difference after $24 \mathrm{~h}$. - magnitude of reduction compared to control, + increase in the viability compared to control.

Table 3. Antimicrobial activity of amurca methanolic extract ( 20 to $60 \mu \mathrm{l} / \mathrm{ml}$ ) against selected foodborne pathogens strains at $10{ }^{\circ} \mathrm{C}$ by $7 \mathrm{~d}$.

\begin{tabular}{|c|c|c|c|c|c|}
\hline Organism & $\begin{array}{l}\text { Initial number } \\
\left(\log _{10} \mathrm{CFU} / \mathrm{ml}\right) \\
\end{array}$ & $\begin{array}{c}\text { Control count, } 7 \mathrm{~d} \\
\left(\log _{10} \mathrm{CFU} / \mathrm{ml}\right)\end{array}$ & $\begin{array}{c}\text { Amurca concentration } \\
(\mu \mathrm{l} / \mathrm{ml})\end{array}$ & $\begin{array}{l}\text { Count after treatment, } \\
7 \mathrm{~d}\left(\log _{10} \mathrm{CFU} / \mathrm{ml}\right)\end{array}$ & $\begin{array}{c}\text { Reduction* } \\
\left(\log _{10} \mathrm{CFU} / \mathrm{ml}\right) \\
\end{array}$ \\
\hline E. coli $\mathrm{O} 157: \mathrm{H} 7$ 02-0628 & $6.0 \pm 0.05$ & $9.3 \pm 0.20$ & $\begin{array}{l}20 \\
40 \\
60\end{array}$ & $\begin{array}{c}9.1 \pm 0.10 \\
6.5 \pm 0.10 \\
\mathrm{ND}\end{array}$ & $\begin{array}{l}-0.2 \\
-2.8 \\
-9.3\end{array}$ \\
\hline E. coli O157:H7 02-0304 & $5.8 \pm 0.17$ & $9.1 \pm 0.10$ & $\begin{array}{l}20 \\
40 \\
60\end{array}$ & $\begin{array}{l}8.8 \pm 0.20 \\
6.6 \pm 0.20 \\
\text { ND }\end{array}$ & $\begin{array}{l}-0.3 \\
-2.5 \\
-9.1\end{array}$ \\
\hline L. monocytogenes 1 & $5.3 \pm 0.05$ & $9.5 \pm 0.20$ & $\begin{array}{l}20 \\
40 \\
60\end{array}$ & $\begin{array}{l}9.2 \pm 0.10 \\
6.3 \pm 0.20 \\
\text { ND }\end{array}$ & $\begin{array}{l}-0.3 \\
-3.2 \\
-9.5\end{array}$ \\
\hline L. monocytogenes 4 & $5.7 \pm 0.17$ & $9.0 \pm 0.10$ & $\begin{array}{l}20 \\
40 \\
60\end{array}$ & $\begin{array}{l}8.9 \pm 0.20 \\
6.2 \pm 0.20 \\
\text { ND }\end{array}$ & $\begin{array}{l}-0.1 \\
-2.8 \\
-9.0\end{array}$ \\
\hline S. Enteritidis & $5.9 \pm 0.05$ & $9.4 \pm 0.40$ & $\begin{array}{l}20 \\
40 \\
60\end{array}$ & $\begin{array}{l}9.1 \pm 0.10 \\
6.6 \pm 0.20 \\
\text { ND }\end{array}$ & $\begin{array}{l}-0.3 \\
-2.8 \\
-9.4\end{array}$ \\
\hline S. aureus 26127 & $5.6 \pm 0.16$ & $9.3 \pm 0.30$ & $\begin{array}{l}20 \\
40 \\
60\end{array}$ & $\begin{array}{l}9.0 \pm 0.10 \\
6.3 \pm 0.06 \\
\mathrm{ND}\end{array}$ & $\begin{array}{l}-0.3 \\
-3.0 \\
-9.3\end{array}$ \\
\hline S. aureus 25923 & $5.6 \pm 0.26$ & $9.4 \pm 0.20$ & $\begin{array}{l}20 \\
40 \\
60\end{array}$ & $\begin{array}{l}8.8 \pm 0.20 \\
6.3 \pm 0.20 \\
\text { ND }\end{array}$ & $\begin{array}{l}-0.6 \\
-3.1 \\
-9.4\end{array}$ \\
\hline
\end{tabular}

Values are expressed as mean $\pm \mathrm{SD}(\mathrm{n}=3)$. ND: Bacterial cells were not detected by transferring $0.1 \mathrm{ml}$ to $10 \mathrm{ml}$ TSB and no growth was observed after $24 \mathrm{~h}$ at $37^{\circ} \mathrm{C}$ (detection level was $\leq 1 \mathrm{CFU} / \mathrm{ml})$. ${ }^{\star}$ Difference after $7 \mathrm{~d}$. - magnitude of reduction compared to control, + increase in the viability compared to control.

Although amurca contains 9 times more phenolic compounds than olive oil (Janakat et al., 2013), its inhibitory effects in the present study were less than previously reported for olive oil. For example, the MIC and MBC of olive oil extract were $0.4 \mu \mathrm{l} / \mathrm{ml}$ and $0.93 \mu \mathrm{l} / \mathrm{ml}$, respectively, against $L$. monocytogenes at $37^{\circ} \mathrm{C}$ (Bubonja-Sonje et al., 2011). Virgin olive oil also reduced L. monocytogenes and $S$. Enteritidis numbers by approximately $3 \log \mathrm{CFU} / \mathrm{g}$ after $30 \mathrm{~min}$ in mayonnaise and salads (Medina et al., 2007). These differences in antimicrobial action may have been the result of variation in the phenolic profiles of the olive oil and amurca as well as differences in the concentration and activity of specific compounds in these products. The most bactericidal phenolic compounds in olive oil were found to be the dialdehydic form of decarboxymethyl 
Janakat et al.

Table 4. Relative antimicrobial activity ${ }^{1}$ of $80 \mu \mathrm{l} / \mathrm{ml}$ amurca methanolic extract against selected Gram-negative pathogenic strains.

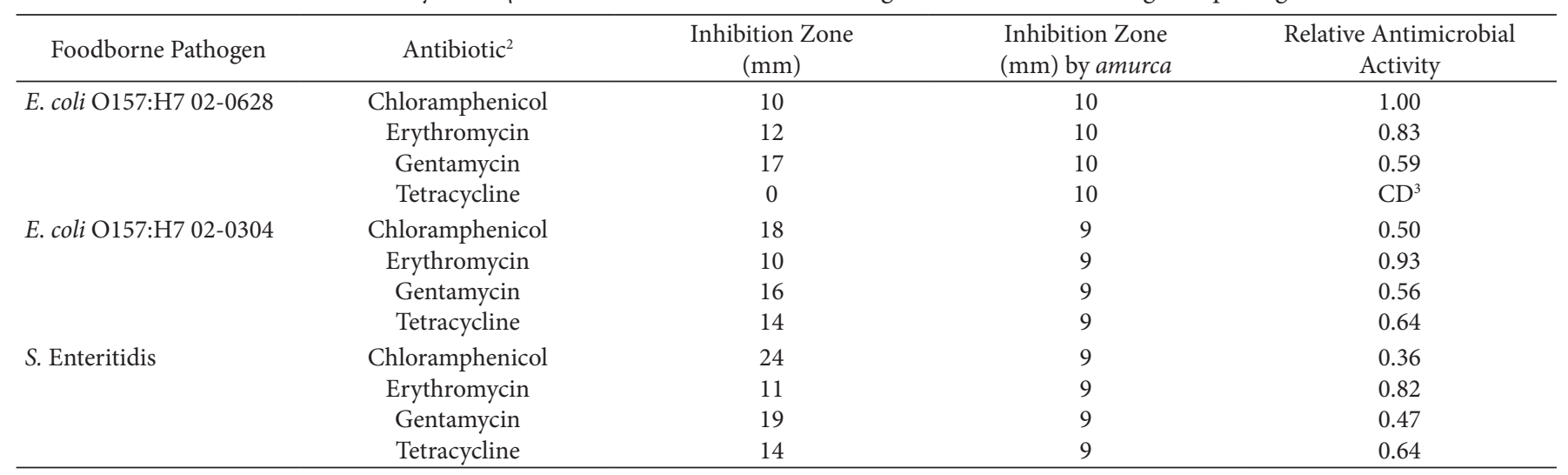

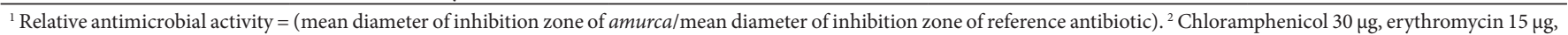
gentamycin $10 \mu \mathrm{g}$, tetracycline $30 \mu \mathrm{g} .{ }^{3} \mathrm{CD}$, calculated differently. Relative inhibition was estimated as 10 -fold greater for amurca.

Table 5. Relative antimicrobial activity ${ }^{1}$ of $80 \mu \mathrm{l} / \mathrm{ml}$ amurca methanolic extract against selected Gram-positive pathogenic strains.

\begin{tabular}{|c|c|c|c|c|}
\hline Bacterial strain & Antibiotic $^{2}$ & $\begin{array}{l}\text { Inhibition zone } \\
(\mathrm{mm})\end{array}$ & $\begin{array}{l}\text { inhibition zone (mm) by } \\
\text { amurca }\end{array}$ & $\begin{array}{l}\text { Relative antimicrobial } \\
\text { activity }\end{array}$ \\
\hline \multirow[t]{4}{*}{ L. monocytogenes 1} & Chloramphenicol & 20 & 9 & 0.45 \\
\hline & Erythromycin & 11 & 9 & 0.82 \\
\hline & Gentamycin & 16 & 9 & 0.56 \\
\hline & Tetracycline & 12 & 9 & 0.75 \\
\hline \multirow[t]{4}{*}{ L. monocytogenes 4} & Chloramphenicol & 20 & 9 & 0.45 \\
\hline & Erythromycin & 11 & 9 & 0.82 \\
\hline & Gentamycin & 15 & 9 & 0.60 \\
\hline & Tetracycline & 12 & 9 & 0.75 \\
\hline \multirow[t]{4}{*}{ S. aureus 26127} & Chloramphenicol & 0 & 20 & $\mathrm{CD}^{3}$ \\
\hline & Erythromycin & 13 & 20 & 1.54 \\
\hline & Gentamycin & 20 & 20 & 1.00 \\
\hline & Tetracycline & 10 & 20 & 2.00 \\
\hline \multirow[t]{4}{*}{ S. aureus 25923} & Chloramphenicol & 21 & 9 & 0.43 \\
\hline & Erythromycin & 11 & 9 & 0.82 \\
\hline & Gentamycin & 18 & 9 & 0.50 \\
\hline & Tetracycline & 14 & 9 & 0.64 \\
\hline
\end{tabular}

${ }^{1}$ Relative antimicrobial activity $=\left(\right.$ mean diameter of inhibition zone of amurca/mean diameter of inhibition zone of reference antibiotic) ${ }^{2} \mathrm{Chloramphenicol} 30 \mu \mathrm{g}$, erythromycin $15 \mu \mathrm{g}$, gentamycin $10 \mu \mathrm{g}$, tetracycline $30 \mu \mathrm{g} .{ }^{3} \mathrm{CD}$, calculated differently. Relative inhibition was estimated as 20 -fold greater for amurca.

Table 6. The $\log _{10}$ number of selected foodborne pathogens in the presence of 40 to $80 \mu \mathrm{l} / \mathrm{ml}$ of ammonium sulfate-precipitated protein from amura methanolic extract at $37^{\circ} \mathrm{C}$.

\begin{tabular}{|c|c|c|c|c|c|}
\hline \multirow{2}{*}{ Organism } & \multirow{2}{*}{$\begin{array}{l}\text { Initial number } \\
\left(\log _{10} \mathrm{CFU} / \mathrm{ml}\right)\end{array}$} & \multicolumn{4}{|c|}{ Bacterial numbers $\left(\log _{10} \mathrm{CFU} / \mathrm{ml}\right)$ at amurca concentration $(\mu \mathrm{l} / \mathrm{ml})$ in ASPP after $24 \mathrm{~h}$ at $37^{\circ} \mathrm{C}$} \\
\hline & & 0 & 40 & 60 & 80 \\
\hline E. coli $\mathrm{O} 157: \mathrm{H} 702-0628$ & $5.6 \pm 0.31^{\mathrm{b}}$ & $9.6 \pm 0.10^{\mathrm{a}}$ & $9.4 \pm 0.30^{\mathrm{a}}$ & $9.5 \pm 0.22^{\mathrm{a}}$ & $9.4 \pm 0.23^{\mathrm{a}}$ \\
\hline E. coli O157:H7 02-0304 & $5.8 \pm 0.20^{\mathrm{b}}$ & $9.4 \pm 0.16^{\mathrm{a}}$ & $9.4 \pm 0.10^{\mathrm{a}}$ & $9.2 \pm 0.20^{\mathrm{a}}$ & $9.3 \pm 0.16^{\mathrm{a}}$ \\
\hline L. monocytogenes 4 & $5.7 \pm 0.11^{\mathrm{b}}$ & $9.3 \pm 0.24^{\mathrm{a}}$ & $9.2 \pm 0.10^{\mathrm{a}}$ & $9.3 \pm 0.31^{\mathrm{a}}$ & $9.4 \pm 0.20^{\mathrm{a}}$ \\
\hline S. Enteritidis & $5.9 \pm 0.19^{\mathrm{b}}$ & $9.2 \pm 0.21^{\mathrm{a}}$ & $9.5 \pm 0.20^{\mathrm{a}}$ & $9.2 \pm 0.15^{\mathrm{a}}$ & $9.2 \pm 0.10^{\mathrm{a}}$ \\
\hline
\end{tabular}

Values are expressed as mean $\pm \mathrm{SD}(\mathrm{n}=3)$. $P$-values were calculated by Students $t$-test. Means with different superscripts a,b, differ significantly $P<0.05$. ASPP indicates ammonium sulfate-precipitated protein.

oleuropein and ligstroside aglycones, hydroxytyrosol and tyrosol (Medina et al., 2006). The MICs of oleuropein and hydroxytyrosol against $S$. aureus strain 25923 and Salmonella Typhi strain 6539 were 0.24 to $7.85 \mu \mathrm{g} / \mathrm{ml}$ and 62.5 to $500 \mu \mathrm{g} / \mathrm{ml}$, respectively (Bisignano et al., 1999).
In general, Gram-positive bacteria are more sensitive to olive oil than Gram-negatives (Medina et al., 2007). In the present study, L. monocytogenes 4 and S. aureus 26127 had lower amurca $\mathrm{MBCs}$ at $37^{\circ} \mathrm{C}$ than the other organisms. CasasSanchez et al. (2007) also reported that Gram-negative bacteria 
were more resistant than Gram-positive bacteria towards oleuropein. This may be attributed to the protection from amurca exposure afforded the Gram-negatives by their outer cell (wall) membrane, which is absent from Gram-positive bacteria.

The antimicrobial activity of olive products (olive fruit, olive oil, olive leaves) and olive oil by-products against foodborne pathogens at refrigerated temperatures have not been previously reported, except that Ferrer et al. (2009) found that 1.5 to $5 \mu \mathrm{l} / \mathrm{ml}$ olive powder inhibited growth of $B$. cereus at $7^{\circ} \mathrm{C}$. The inhibitory effects of amurca were improved by lower storage temperature as reflected by the lower MICs and MBCs at $10^{\circ} \mathrm{C}$ compared to $37^{\circ} \mathrm{C}$, but complete bacterial inactivation took longer at $10^{\circ} \mathrm{C}$. It is likely that the lower temperature delayed the hydrolytic and oxidative degradation of phenolic compounds in the amurca extract. It has been reported that the total phenolic content of olive oil was increased in cold pressed olives (Parenti et al., 2008). Also, oil that was obtained from olives stored at 5 to $10^{\circ} \mathrm{C}$ experienced lower hydrolytic, oxidative degradation and off-odour development (Clodoveo et al., 2007; Inarejos-García et al., 2010). Therefore, amurca extract should be considered a potential natural antimicrobial for enhancing the keeping quality of foods that will be stored for extended periods at refrigerated temperatures.

The increased occurrence of foodborne pathogens resistant towards antibiotics puts pressure on authorities that regulate their clinical and agricultural use, but serves as motivation for researchers to find effective natural antimicrobials to use as food preservatives. The effectiveness of natural antimicrobials, such as plant-derived antimicrobials have been demonstrated against foodborne pathogens (Holley \& Patel, 2005; Tajkarimi et al., 2010). The results of the present study indicated that amurca extract was inhibitory to some antibiotic resistant bacteria which suggests amurca extract might be used as an alternative hurdle to address the more frequent occurrence of antibiotic resistant bacteria in the environment, thus reducing the risk associated with foodborne pathogen infection.

\section{Conclusions}

The results showed that amurca extract has potent antimicrobial activity against Gram-positive (L. monocytogenes and S. aureus) and Gram-negative (E. coli O157:H7 and $S$. Enteritidis) foodborne pathogens. Further, amurca extract was inhibitory to two antibiotic resistant pathogenic bacteria. The greater antimicrobial activity of amurca extract at $10^{\circ} \mathrm{C}$ than $37^{\circ} \mathrm{C}$ may prove to be of value for maintaining the safe shelf-life of perishable foods. This antibacterial activity may be explained by the high content of phenolic compounds in the amurca extract. Further investigation will be conducted to evaluate the effectiveness of amurca extract in inhibiting the foodborne pathogens in model food systems and examine the sensory qualities of foods treated with the amurca extract.

\section{Acknowledgements}

The authors thank the Deanship of Research at Jordan University of Science and Technology (JUST) for providing the financial support for this project (17/2010). We also thank Dr. Mohammad Alrababah for the generous donation of amurca from his mill.

\section{References}

Al-Nabulsi, A. A., Osaili, T. M., Elabedeen, N. A., Jaradat, Z. W., Shaker, R. R., Kheirallah, K. A., Tarazi, Y. H., \& Holley, R. A. (2011). Impact of environmental stress desiccation, acidity, alkalinity, heat or cold on antibiotic susceptibility of Cronobacter sakazakii. International Journal of Food Microbiology, 146(2), 137-143. http://dx.doi. org/10.1016/j.ijfoodmicro.2011.02.013. PMid:21402424

Amici, A., Verna, M., \& Martillotti, F. (1991). Olive by-products in animal feeding: improvement and utilization. Options Méditerranéennes, 16, 149-152.

Bisignano, G., Tomaino, A., Lo Cascio, R., Crisafi, G., Uccella, N., \& Saija, A. (1999). On the in-vitro antimicrobial activity of oleuropein and hydroxytyrosol. The Journal of Pharmacy and Pharmacology, 51(8), 971-974. http://dx.doi.org/10.1211/0022357991773258. PMid:10504039

Bubonja-Sonje, M., Giacometti, J., \& Abram, M. (2011). Antioxidant and antilisterial activity of olive oil, cocoa and rosemary extract polyphenols. Food Chemistry, 127(4), 1821-1827. http://dx.doi. org/10.1016/j.foodchem.2011.02.071.

Capasso, R., Evidente, A., Schivo, L., Orru, G., Marcialis, M. A., \& Cristinzio, G. (1995). Antibacterial polyphenols from olive oil mill waste waters. The Journal of Applied Bacteriology, 79(4), 393-398. http://dx.doi.org/10.1111/j.1365-2672.1995.tb03153.x. PMid:7592132

Caputo, A. C., Scacchia, F., \& Pelagagge, P. M. (2003). Disposal of byproducts in olive oil industry: waste-to-energy solutions. Applied Thermal Engineering, 23(2), 197-214. http://dx.doi.org/10.1016/ S1359-4311(02)00173-4.

Casas-Sanchez, J., Asuncion Alsina, M., Herrlein, M. K., \& Mestres, C. (2007). Interaction between the antibacterial compound, oleuropein, and model membranes. Colloid \& Polymer Science, 285(12), 1351-1360. http://dx.doi.org/10.1007/s00396-007-1693-x.

Caturla, N., Pérez-Fons, L., Estepa, A., \& Micol, V. (2005). Differential effects of oleuropein, a biophenol from Olea europaea, on anionic and zwiterionic phospholipid model membranes. Chemistry and Physics of Lipids, 137(1-2), 2-17. http://dx.doi.org/10.1016/j. chemphyslip.2005.04.003. PMid:16002058

Ceylan, E., \& Fung, D. Y. C. (2004). Antimicrobial activity of spices. Journal of Rapid Methods and Automation in Microbiology, 12(1), 1-55. http://dx.doi.org/10.1111/j.1745-4581.2004.tb00046.x.

Clodoveo, M. L., Delcuratolo, D., Gomes, T., \& Colelli, G. (2007). Effect of different temperatures and storage atmospheres on Coratina olive oil quality. Food Chemistry, 102(3), 571-576. http://dx.doi. org/10.1016/j.foodchem.2006.05.035.

Ferrer, C., Ramón, D., Muguerza, B., Marco, A., \& Martínez, A. (2009). Effect of olive powder on the growth and inhibition of Bacillus cereus. Foodborne Pathogens and Disease, 6(1), 33-37. http://dx.doi. org/10.1089/fpd.2008.0133. PMid:19061367

Gupat, C., Garg, A. P., Uniyal, R. C., \& Kumari, A. (2008). Antimicrobial activity of some herbal oils against common food-borne pathogens. African Journal of Microbiological Research, 2, 258-261.

Harwood, J. L., \& Aparicio, R. (2000). Handbook of olive oil analysis and properties (pp. 17-18). Gaithersburg: Aspen Publisher.

Hashemite Kingdom of Jordan, Department of Statistics. (2007). The agricultural census. Retrieved from http://www.dos.gov.jo/agr/ agr_a/haiawanieh/tabels/tab6.5.pdf.

Holley, R. A., \& Patel, D. (2005). Improvement of shelf-life and safety of perishable foods by plant essential oils and smoke antimicrobials. Food Microbiology, 22(4), 273-292. http://dx.doi.org/10.1016/j. fm.2004.08.006. 
Inarejos-García, A. M., Gómez-Rico, A., Desamparados Salvador, M., \& Fregapane, G. (2010). Effect of preprocessing olive storage conditions on virgin olive oil quality and composition. Journal of Agricultural and Food Chemistry, 58(8), 4858-4865. http://dx.doi. org/10.1021/jf902486f. PMid:20356076

Janakat, S., Al-Fakhiri, S., \& Sallal, A. K. (2004). A promising peptide antibiotic from Terfezia claveryi extracts against Staphylococcus aureus. Phytotherapy Research, 18(10), 810-813. http://dx.doi. org/10.1002/ptr.1563. PMid:15551385

Janakat, S. M., Al-Fakhiri, S. M., \& Sallal, A. K. (2005). Evaluation of antibacterial activity of aqueous and methanolic extracts of the truffle Terfezia claveryi against Pseudomonas aeruginosa. Saudi Medical Journal, 26(6), 952-955. PMid:15983681.

Janakat, S., Al-Nabulsi, A., Hammad, F., \& Holley, R. (2013). Effect of amurca on olive oil quality during storage. Journal of Food Science and Technology. In press. http://dx.doi.org/10.1007/s13197-0131153-1.

Janakat, S., \& Hammad, F. (2013). Chemical composition of amurca generated from Jordanian olive oil. Journal of Nutritional \& Food Sciences, 3(2), 186. http://dx.doi.org/10.4172/2155-9600.1000186.

Kapellakis, I. E., Tsagarakis, K. P., \& Crowther, J. C. (2008). Olive oil history, production and by-product management. Reviews in Environmental Science and Biotechnology, 7(1), 1-26. http://dx.doi. org/10.1007/s11157-007-9120-9.

Kecel, T., \& Robinson, R. K. (2002). Antimicrobial activity of phenolic extracts from virgin olive oil. Milchwissenschaft. Milk Science International, 57, 436-440.

Lowry, O. H., Rosebrough, N. J., Farr, A. L., \& Randall, R. J. (1951). Protein measurement with the Folin phenol reagent. The Journal of Biological Chemistry, 193(1), 265-275. PMid:14907713.

Markin, D., Duek, L., \& Berdicevsky, I. (2003). In vitro antimicrobial activity of olive leaves. Mycoses, 46(3-4), 132-136. http://dx.doi. org/10.1046/j.1439-0507.2003.00859.x. PMid:12870202

Medina, E., de Castro, A., Romero, C., \& Brenes, M. (2006). Comparison of the concentrations of phenolic compounds in olive oils and other plant oils: correlation with antimicrobial activity. Journal of Agricultural and Food Chemistry, 54(14), 4954-4961. Retrieved from http://pubs.acs.org/doi/abs/10.1021/jf0602267. http://dx.doi.org/10.1021/jf0602267. PMid:16819902

Medina, E., Romero, C., Brenes, M., \& De Castro, A. (2007). Antimicrobial activity of olive oil, vinegar, and various beverages against foodborne pathogens. Journal of Food Protection, 70(5), 1194-1199. PMid:17536679.

Niaounakis, M., \& Halvadakis, C. (2006). Olive processing waste management (pp. 23-24, 237-240). London: Elsevier.

Parenti, A., Spugnoli, P., Masella, P., \& Calamai, L. (2008). The effect of malaxation temperature on the virgin olive oil phenolic profile under laboratory-scale conditions. European Journal of Lipid
Science and Technology, 110(8), 735-741. http://dx.doi.org/10.1002/ ejlt.200700307.

Pereira, A. P., Ferreira, I. C., Marcelino, F., Valentão, P., Andrade, P. B., Seabra, R., Estevinho, L., Bento, A., \& Pereira, J. A. (2007). Phenolic compounds and antimicrobial activity of olive (Olea europaea L. Cv. Cobrançosa) leaves. Molecules (Basel, Switzerland), 12(5), 11531162. http://dx.doi.org/10.3390/12051153. PMid:17873849

Pereira, J. A., Pereira, A. P., Ferreira, I. C., Valentão, P., Andrade, P. B., Seabra, R., Estevinho, L., \& Bento, A. (2006). Table olives from Portugal: phenolic compounds, antioxidant potential, and antimicrobial activity. Journal of Agricultural and Food Chemistry, 54(22), 8425-8431. http://dx.doi.org/10.1021/jf061769j. PMid:17061816

Quiles, J. L., Ramirez-Tortos, M. C., \& Yaqoob, P. (2006). Olive oil and health. (pp. 13-17). London: CABI Publishing.

Ramos-Cormenzana, A., Juarez-Jimenez, B., \& Garcia-Pareja, M. P. (1996). Antimicrobial activity of olive mill waste-waters (alpechin) and biotransformed olive oil mill wastewater. International Biodeterioration \& Biodegradation, 38(3-4), 283-290. http://dx.doi. org/10.1016/S0964-8305(96)00061-3.

Smith, A. E., \& Secoy, D. M. (1975). Forerunners of pesticides in classical Greece and Rome. Journal of Agricultural and Food Chemistry, 23(6), 1050-1055. http://dx.doi.org/10.1021/jf60202a004. PMid:1104693

Soler-Rivas, C., Espin, J. C., \& Wichers, H. J. (2000). Oleuropein and related compounds. Journal of the Science of Food and Agriculture, 80, 1013-1023. http://dx.doi.org/10.1002/(SICI)10970010(20000515)80:7<1013::AID-JSFA571>3.0.CO;2-C.

Sudjana, A. N., D’Orazio, C., Ryan, V., Rasool, N., Ng, J., Islam, N., Riley, T. V., \& Hammer, K. A. (2009). Antimicrobial activity of commercial Olea europaea (olive) leaf extract. International Journal of Antimicrobial Agents, 33(5), 461-463. http://dx.doi.org/10.1016/j. ijantimicag.2008.10.026. PMid:19135874

Tajkarimi, M. M., Ibrahim, S. A., \& Cliver, D. O. (2010). Antimicrobial herb and spice compounds in food. Food Control, 21(9), 1199-1218. http://dx.doi.org/10.1016/j.foodcont.2010.02.003.

Tassou, C. C., \& Nychas, G. J. (1995). Inhibition of Salmonella enteritidis by oleuropein in broth and in a model food system. Letters in Applied Microbiology, 20(2), 120-124. http://dx.doi. org/10.1111/j.1472-765X.1995.tb01301.x. PMid:7765901

Tassou, C. C., Nychas, G. J., \& Board, R. G. (1991). Effect of phenolic compounds and oleuropein on the germination of Bacillus cereus T spores. Biotechnology and Applied Biochemistry, 13(2), 231-237. PMid:1904245.

Tranter, H. S., Tassou, S. C., \& Nychas, G. J. (1993). The effect of the olive phenolic compound, oleuropein, on growth and enterotoxin $\mathrm{B}$ production by Staphylococcus aureus. The Journal of Applied Bacteriology, 74(3), 253-259. http://dx.doi. org/10.1111/j.1365-2672.1993.tb03023.x. PMid:8468258 